\title{
The effect of measurable and regular exercise on ovariectomized Sprague Dawley rats in improving skin quality
}

\author{
Lutfi Nurdian Asnindari ${ }^{1 *}$, Sri Kadarsih Soejono, ${ }^{2}$ Haryadi $^{3}$ \\ ${ }^{1}$ Study Program of Master in Biomedical Sciences, Postgraduate Program of Faculty \\ Medicine, Public Health and Nursing, Universitas Gadjah Mada, Yogyakarta, ${ }^{2}$ Department \\ of Physiology, Faculty Medicine, Public Health and Nursing, Universitas Gadjah Mada, \\ Yogyakarta, ${ }^{3}$ Department of Anatomic Pathology, Faculty Medicine, Public Health and \\ Nursing, Universitas Gadjah Mada, Yogyakarta, Indonesia
}

DOI: http://dx.doi.org/10.19106/JMedScie/005003201803

\section{ABSTRACT}

The decline of estrogen level causes various skin changes including amount of fibroblast, the thickness of epidermis and dermis. Physical exercise is believed can increase the estrogen level and give benefit impacts on skin. It mechanism is often associated with the increase of extragonadal aromatization and estrogen serum, the activation of insulinlike growth factor (IGF), and the expression of estrogen receptor (ER). This study was conducted to investigate the effect of physical exercise in ovariectomized rat on the amount of fibroblast, the thickness of epidermis and dermis, the levels of ER $\beta$ in skin and serum estrogen. Eight female Sprague Dawley rats aged 3 months were used in this study. Rats were divided into two groups i.e. Group 1 consisted of ovariectomized rats without physical exercise and Group 2 consisted of ovariectomized rats and given measurable and regular physical exercise. Rats ran on treadmill with the speed $18 \mathrm{~m} /$ $\mathrm{min}$, the tilt of $5 \%$, duration for $60 \mathrm{~min} / \mathrm{experiment/day,} 5$ times a week for 12 weeks. The amount of fibroblast, the thickness of epidermis and dermis, the levels of ER $\beta$ in skin and serum estrogen were measured after physical exercise. The result showed that there was a significant difference amount of fibroblast between group 1 and group $2(p<0.05)$. However, no significant difference the levels of serum estrogen, ER $\beta$, and the thickness of epidermis and dermis between Group 1 and Group 2 ( $p>0.05)$. There was a significant positive correlation between the level of serum estrogen and the thickness of epidermis $(p<0.05)$, and negative correlation between the serum estrogen level and the level of ER $\beta$ $(p<0.05)$, and negative significant correlation between the level of ER $\beta$ and the thickness of epidermis $(p<0.05)$. In conclusion, the amount of dermal fibroblast of ovariectomized rats increase after underwent measurable and regular exercise. There is correlation between the serum estrogen level and the thickness of epidermis as well as ER $\beta$.

\section{ABSTRAK}

Penurunan kadar estrogen dapat menyebabkan perubahan kulit termasuk jumlah fibroblast, ketebalan epidermis dan dermis. Latihan fisik dapat meningkatkan kadar estrogen dan berdampak positif pada kulit. Mekanismenya berhubungan dengan peningkatan aromatisasi ekstragonadal, peningkatan estrogen serum, aktivasi insulinlike growth factor (IGF), serta ekspresi reseptor estrogen (RE). Penelitian ini bertujuan mengkaji pengaruh latihan fisik pada tikus yang dilakukan ovariektomi terhadap jumlah fibroblast, ketebalan epidermis dan dermis, kadar RE $\beta$ kulit, dan kadar estrogen serum. 
Delapan ekor tikus Sprague Dawley betina umur 3 bulan digunakan dalam penelitian ini. Tikus dibagi menjadi dua kelompok yaitu Kelompok 1 tikus dilakukan ovariektomi dan tidak diberi latihan fisik dan Kelompok 2 tikus dilakukan ovariektomi dan diberi latihan fisik teratur dan terukur. Tikus berlari di atas treadmill dengan kecepatan $18 \mathrm{~m} / \mathrm{menit}$, kemiringan $5 \%$, durasi 60 menit/kali/hari, dan frekuensi 5 kali per minggu, selama 12 minggu. Setelah latihan fisik teratur dan terukut, jumlah fibroblast, ketebalan epidermis dan dermis, kadar RE $\beta$ kulit dan estrogen serum diukur. Hasil penelitian menunjukkan bahwa terdapat perbedaan bermakna rerata jumlah fibroblast antara Kelompok 1 dan Kelompok $2(p<0,05)$. Namun, tidak terdapat perbedaan bermakna untuk rerata kadar estrogen serum, kadar RE $\beta$, ketebalan epidermis dan dermis antara Kelompok 1 dan Kelompok 2 ( $p>0,05)$. Terdapat hubungan positif yang bermakna antara kadar estrogen serum dengan ketebalan epidermis $(p<0,05)$ dan hubungan negatif antara kadar estrogen serum dengan kadar RE $\beta$ kulit serta hubungan negatif yang bermakna antara kadar RE $\beta$ kulit dengan ketebalan epidermis $(p<0,05)$. Dapat disimpulkan, jumlah fibroblas dermis tikus yang menjalani latihan fisik teratur dan terukur lebih besar dibandingkan tanpa latihan fisik teratur dan terukur pada tikus yang dilakukan ovariektomi. Terdapat hubungan antara kadar estrogen serum dan ketebalan epidermis dan juga RE $\beta$.

Keywords: physical exercise - serum estrogen - estrogen $\beta$ receptor - fibroblast - dermis - epidermis.

\section{INTRODUCTION}

The decline of estrogen level in postmenopausal woman shows various impacts such as low content of collagen in skin, increase of the numbers and the depth of wrinkles, skin depletion, dryness in skin and low elasticity. ${ }^{1,2}$ In addition, low estrogen level may cause long wound healing and atrophy. ${ }^{3}$ In young rats after ovariectomy (OVX), visible skin deteriorations are found such as low number of collagen fibers in skin, ${ }^{4}$ the decrease of subcutaneous tissue's thickness, the increase of breaking strength, tensile strength and Young's skin modulus. ${ }^{5}$ The decrease in the thickness of epidermis, dermis and the percentage of dermis collagen are also found in the young rabbits after OVX. ${ }^{6}$

One of most convenient methods to elevate estrogen level is physical exercise. Regular physical exercise with medium intensity is proven can increase the serum estrogen level on rats after $\mathrm{OVX}^{7}$ and on post-menopausal women. ${ }^{8}$ Regular physical exercise can also increase the CYP19 expression in adrenal cortex and fat tissue. ${ }^{9}{ }^{10}$ Furthermore, estrogen level in cerebellum $^{11}$ and hippocampus ${ }^{12}$ of rats after OVX increases as the result of measurable and regular physical exercise for 12 weeks

Physical exercise gives also significant impact on the expression of estrogen receptor (ER) in liver, heart and muscles. ${ }^{7,13}$ The expression of particular hormone's receptor can change along with the physiologic need of one tissue on that hormone. ${ }^{14}$ Physical exercise also elevates the level of insulinlike growth factor-1 (IGF-1). ${ }^{15}$ The IGF1 is promoting cell growth involved in keratinocytes proliferation ${ }^{16}$ and fibroblast so that the decreasing number of IGF1 contributes to the decrease of skin thickness. ${ }^{17}$ It is also able to form cross talk (cross interaction which influences each other) with ER. The IGF-1 activates mitogen activated protein kinase (MAPK) cascade which phosphorylates transcription factor leading to increasing the transcription activity of ER. ${ }^{18}$ The ER $\boldsymbol{\beta}$ plays dominant role in regulating the action of estrogen in skin. ${ }^{19}$

This study aimed to investigate the effect of measurable and regular physical 
exercise on serum estrogen level and ER $\beta$ level in skin on ovariectomized Sprague Dawley rats. Their effect on the amount of fibroblast and the thickness of epidermis and dermis of the rats was also evaluated.

\section{MATERIALS AND METHODS}

\section{Animal model procedure}

This was an experimental study using post test only control group design involving eight female Sprague Dawley rats aged about 3 months. Before experimental, rats were adapted in individual cage for 7 days before OVX. Following after OVX, the rats were adapted again for 7 days for OVX wound healing and hormonal adaptation. On the $15^{\text {th }}$ day, these rats were randomly divided into two groups with four rats for each group. Group 1 consisted of rats underwent OVX without physical exercise, whereas Group 2 consisted of rats underwent OVX with regular and measurable physical exercise.

Gradual adaptation of the physical exercise on the rats of Group 2 was conducted on the $15^{\text {th }}$ to $21^{\text {st }}$ day. Furthermore, the physical exercise was initiated for 5 days a week (Monday, Tuesday, Wednesday, Friday, and Saturday) for 12 weeks with medium intensity and the tilt of $5 \%$. The duration of the physical exercise was 60 min consisting 10 min of warming up with the speed of $12 \mathrm{~m} /$ min, $40 \mathrm{~min}$ for main exercise with the speed of $18 \mathrm{~m} / \mathrm{min}$, and $10 \mathrm{~min}$ for cooling down with the speed of $12 \mathrm{~m} / \mathrm{min}^{7}$ On the $106^{\text {th }}$ day, the rats were anesthetized using $\mathrm{HCl}$ ketamine. Following after the rats lose their consciousness, blood and skin samples were taken. The blood sample was taken through orbitalis sinus for the estrogen serum level measurement. Two sample of skin tissues were taken by using $5 \mathrm{~mm}$-punch biopsy on left leg. One fresh the skin tissue sample was used for the skin ER $\beta$ level measurement and another one was dipped into formalin $10 \%$ to produce paraffin block. Furthermore, HE staining was conducted to examine the amount of fibroblast and the thickness of dermis and epidermis.

Examination of serum estrogen level, ERß, dermis fibroblast and epidermis thickness

The serum estrogen and skin ER $\beta$ levels were measured by using ELISA technique. The amount of dermis fibroblast was measured in 10 microscope fields of view at a magnification of $200 \mathrm{x}$ after HE staining. The thickness of epidermis and dermis were measured by using Optilab®Image Raster version 2.10 n 10 different places.

\section{Statistical analysis}

Data were presented as mean \pm SEM. The different of serum estrogen level, skin ER $\beta$ level, dermis fibroblast and epidermis thickness of the both groups were analyzed using paired $t$ test. Moreover, the relationship between the variables were analyzed using Pearson correlation. A $p$ value $<0.05$ was considered to be significant.

\section{RESULTS}

Serum estrogen and ER $\beta$ levels, amount of fibroblast, thickness of epidermis and dermis

No significantly different in the serum estrogen level, skin ER $\beta$ level and thickness of epidermis as well as thickness of dermis between the rats underwent OVX with physical exercise (Group 2) and those without physical exercise (Group 1) were observed. However, the amount of fibroblast on Group $2(15.75 \pm 1.70)$ was significantly higher than that on Group $1(8.75 \pm 0.48)$ $(\mathrm{p}<0.05)$ as presented in TABLE 1 . It was indicated that the regular and measurable physical exercise on the rats underwent OVX increased the amount of fibroblast, however, did not influence the serum estrogen level, skin ER $\beta$ level, thickness of epidermis and thickness of dermis. 
TABLE 1. Serum estrogen and ER $\beta$ levels, amount of fibroblast, thickness of epidermis, and thickness of dermis (mean \pm SEM) in both groups of rats

\begin{tabular}{lllll}
\hline Variable & Group & $\mathrm{n}$ & Mean \pm SEM & $\mathrm{p}$ \\
\hline Serum estrogen level $(\mathrm{ng} / \mathrm{mL})$ & 1 & 4 & $24.23 \pm 10.99$ & \multirow{2}{*}{0.761} \\
& 2 & 4 & $28.03 \pm 4.59$ & \\
ER $\beta$ level $(\mathrm{pg} / \mathrm{mL} / 50 \mathrm{mg}$ tissue) & 1 & 3 & $0.028 \pm 0.067$ & 0.260 \\
& 2 & 4 & $0.019 \pm 0.004$ & \\
Amount of fibroblast & 1 & 4 & $8.75 \pm 0.48$ & \multirow{2}{*}{$0.007^{*}$} \\
\multirow{2}{*}{ Thickness of epidermis $(\mu \mathrm{m})$} & 2 & 4 & $15.75 \pm 1.70$ & \\
\multirow{2}{*}{ Thickness of dermis $(\mu \mathrm{m})$} & 1 & 4 & $2.93 \pm 0.24$ & 0.199 \\
& 2 & 4 & $3.35 \pm 0.17$ & \\
& 1 & 4 & $63.13 \pm 2.52$ & 0.112
\end{tabular}

Note: Group 1 : rats underwent OVX without physical exercise; Group 2: rats underwent OVX with regular and measurable physical exercise; *significant $(\mathrm{p}<0.05)$

Correlation between the serum estrogen, ER $\beta$ levels and amount of fibroblast, the thickness of epidermis as well as dermis

Negative correlation between the serum estrogen level and the thickness of epidermis $(\mathrm{r}=-0.832 ; \mathrm{p}=0.029)$, positive correlation between the skin ER $\beta$ level and the thickness of epidermis $(r=0.759 ; \mathrm{p}=$ $0.040)$ and negative correlation between the serum estrogen level and skin ER $\beta$ level $(r$ $=-0.911 ; \mathrm{p}=0.011)$ were reported in this study (TABLE 2). It was indicated that the serum estrogen level increases the thickness of epidermis. In contrast, the skin ER $\beta$ decreases the thickness of epidermis.

TABLE 2. The Pearson Correlation analysis

\begin{tabular}{llll}
\hline & Correlation & \multicolumn{1}{c}{$\mathrm{r}$} & $\mathrm{p}$ \\
\hline \multirow{3}{*}{ Serum estrogen level } & Amount of fibroblast & -0.244 & 0.861 \\
& Thickness of dermis & 0.564 & 0.582 \\
& Thickness of epidermis & -0.832 & $0.029^{*}$ \\
& Amount of fibroblast & -0.074 & 0.641 \\
Skin ER $\beta$ level & Thickness of dermis & -0.231 & 0.244 \\
& Thickness of epidermis & 0.759 & $0.040^{*}$ \\
Serum estrogen level & Skin ER $\beta$ level & -0.911 & $0.011^{*}$ \\
\hline
\end{tabular}




\section{DISCUSSION}

The serum estrogen level of the rats underwent OVX with physical exercise (G2) was higher than those without physical exercise (G1), although it was not significantly different (TABLE 1). The mechanism underlying the effect of physical exercise on serum estrogen level is not quite understood. After menopause or OVX, the serum estrogen is produced and secreted by peripheral steroidogenic active glands through extragonadal aromatization process. $^{20,21}$ Due to the following explanation, physical exercise is assumed to increase extragonadal aromatization process. Its mechanism has correlation with the production of IL- 6 during performing endurance exercise. ${ }^{22,23}$

IL-6 is involved in immune response and acute phase reaction. Cytokine that is produced during inflammation can influence the communication between the hypothalamus-pituitary-adrenocortex (HPA) axis and immune system. ${ }^{24}$ Inflammatory stimuli activates anti-inflammation signals from the central nervous system, whereas inflammation in peripheral tissues triggers neural signals in hypothalamus. ${ }^{25}$ Acute phase response stimulates the expression of mRNA IL-6R in hypothalamic nucleus causing IL-6 activates HPA axis. ${ }^{26}$ IL-6 is presumably produced as acute phase response after physical exercise. ${ }^{27}$ These signal induces hypothalamic releasing factors which eventually enhance the secretion of hormone pituitary including adrenocorticotropic hormone $(\mathrm{ACTH}){ }^{28}$

ACTH which is released will result in rapid increase in the formation of pregnenolon and its derivatives, including cortisol and androgen adrenal. In longer period, ACTH elevates the synthesis of P450 which influences the formation of adrenocortex hormones..$^{29} \mathrm{P} 450$ aromatase is an enzyme responsible for converting testosterone into estradiol and androstenedion into estron. ${ }^{30} \mathrm{P} 450$ aromatase can be activated by inflammatory mediator, ${ }^{31}$ one of them is
IL- $6,{ }^{24}$ so that it increases the capability of extragonadal tissue in synthesizing estrogen from androgen. ${ }^{31}$ Estrogen tissues will join the circulation if they do not take part in local metabolism. ${ }^{32}$

The test result on mean of ER $\beta$ level of group given OVX without physical exercise (G1) and group given OVX and physical exercise (G2) shows that mean of those groups have no significant difference $p>0.05$ (TABLE 2). However, mean of ER $\beta$ level of G1 is higher than mean of ER $\beta$ of G2 (TABLE 2). It means that physical exercise decreases ER $\beta$ level of skin in rats after OVX. Factors that influence this to happen are not quite understood, but it is assumed that physical exercise influences steroidogenesis process in skin. DHEA is proven to be converted into estradiol in skin. ${ }^{33}$ Physical exercise is proven to influence steroidogenesis process in several tissues which eventually elevates local estrogen level in tissues. ${ }^{11,12}$ The increase of estrogen level in local tissues is assumed to contribute to ER $\beta$ transcription process leading to decreased level of ER $\beta$ level in skin. Mechanism refers to adaptation of receptor's need on its physiologist need because the adaptation of the number of receptor is very specific in each network. ${ }^{14}$

Besides, it is possible that estrogen mechanism in skin after OVX and physical exercise does not frequently involve genomic response. This assumption is who found that estradiol stimulates the production of skin procollagen in rats and human, although it does not activate ER. Thus, it needs further research focusing on estrogen action mediator. ${ }^{34}$ Mean of the number of fibroblast on group given OVX without physical exercise (K1) compared to group given OVX and physical exercise is significantly different $(p<0.05)$ (TABLE1). Mean of the number of dermal fibroblast of Group 2 is significantly higher than Group 1 (TABLE1). It shows that physical exercise increases the amount of fibroblast in skin. However, the result is still lower than mean of group which gets neither OVX nor 
physical exercise.

No research has ever been conducted on examining the influence of physical exercise on the amount of skin fibroblast. However, the mechanism that might happen correlates with the effect of physical exercise on local steroidogenesis process in skin tissue. Local estrogen plays important role on skin physiology especially fibroblast. ${ }^{35}$ Fibroblast migration and proliferation increase along with the existence of DHEA; however, the effect is hampered by aromatase inhibitor. It shows that fibroblast migration and proliferation depend on the conversion of $17 \beta$ - estradiol.Mechanism of intracrine estrogen action in skin fibroblast indicates that skin fibroblast contains an enzyme converting DHEA into estradiol. ${ }^{33}$

Fibroblasts and dermal papilla cells express $5 \alpha$-reductase tipe $2 .{ }^{36}$ Skin fibroblast express P450 (aromatase). ${ }^{37,38}$ However, this research does not measure the level of estrogen in tissues, enzymes and genes involving in steroidogenesis process in skin; therefore, its underlying mechanism can be clearly explained. Research show that measurable and regular physical exercise increase antioxidant enzyme which serves as the protector against skin deterioration due to free radicals. ${ }^{39}$ The increased expression of catalase enzyme and glutathione peroxidaseon rats after 16 week-physical exercise using freewheel running. Glutathione peroxidase and superoxide dismutaseon rats increase after swimming. ${ }^{40}$ Therefore, measurable and regular physical exercise elevates the ability to prevent any destruction resulted from free radicals..$^{41}$ Physical exercise is also proven to increase the level Insulin-like growth factor-1(IGF-1). ${ }^{15}$ IGF-1 is a growth factor involved in fibroblast proliferation. ${ }^{42}$ Thus, the increased level of IGF-1 elevates fibroblast proliferation.

Physical exercise endurance also significantly increases blood flow. ${ }^{43}$ The increased microcirculation causing increases tissue oxygenation and nutrient delivery. ${ }^{44}$ This mechanism is assumed to increase fibroblast proliferation. The result test on mean of the thickness of epidermis and dermis for group given OVX without physical exercise (G1) compared to group given OVX and physical exercise $(\mathrm{G} 2)$ is not significantly different $\mathrm{p}>0.05$ (TABLE 1 and TABLE 2). It means that measurable and regular physical exercise increases the thickness of epidermis and dermis.

Previous research examining the effect of physical exercise on the thickness of epidermis and dermis has never been conducted before. Mechanism that might happen has correlation with the effect of physical exercise on the local steroidogenesis process in skin tissues. Therefore, local estrogen level will improve the physiology of skin tissue. Moreover, physical exercise elevates antioxidant enzyme will prevent the damage on the component of connective tissue in dermis due to the formation of ROS on skin of OVX-induced rats. ${ }^{39,45,46}$

The changes of skin mechanical structure is associated with age and period after menopause, as it has been stated. ${ }^{5}$ Therefore, age possibility and the length of time after OVX influence the result of research in skin thickness. The age of rats which get OVX also influences the result. ${ }^{46}$ the uses of Wistar rats aged 5 months for research on the biomechanical decrease on rats skin after OVX. ${ }^{5}$ Thus, the age of rats undergoing OVX also has possibility to affect end result of physical exercise on skin thickness.

Besides, there is a final phase in tissue rejuvenation process, namely the remodeling process. This phase has long duration in which incessant synthesis of collagen happens. Collagen damages are renovated and stabilized in a stable condition for 21 days or even weeks after. Remodeling phase occurs during the first week until the $12^{\text {th }}$ week or more.$^{47}$ Hence, before reaching the last period of remodeling, skin thickening will not stop. When reaching stable extracellular matrix, skin thickness will not lengthen as the time passes by. Based on period after OVX, treatment in this research will stop 
in the $12^{\text {th }}$ week because tissue rejuvenation has reached the final phase of remodeling. However, it need time-series based research to ensure this assumption.

A study should be conducted to investigate the relation between ER $\beta$ level and the thickness of epidermis and dermis as well as serum estrogen level with the thickness of epidermis and dermis. From the correlation test on the relation between ER $\beta$ level and the thickness of epidermis, the result shows significant correlation. A significant correlation is visible in serum estrogen level with the thickness of epidermis (TABLE 2). The function of epidermis is proven to be regulated by the circulation of estrogen level, even though estrogen metabolism process and estrogen sensitivity in peripheral tissue also greatly contribute to epidermis homeostasis. In epidermis, estrogen plays important role in keratinocyte proliferation. ${ }^{48}$

Receptor upregulation is one of method to scrutinize the response of intracellular receptor on the increased hormone level. ${ }^{49}$ However, this research finds no significant difference on ER $\beta$ level between G1 and G2. It is possible that estrogen action in skin in order to maintain the thickness of epidermis and dermis genomically occurs through classic pathway depend on ligan. It does not only involve ER $\beta$ but also ER $\alpha$; however, this research will not further discuss this area. Besides, it can also occur through gnomic pathway which does not depend on ligan; however, the capability of GF to activate ER $\beta$ is lower than ER $\alpha .{ }^{50}$

\section{CONCLUSION}

Amount of dermal fibroblast on rats increases after measurable and regular exercise. The increase on the level of serum estrogen elevates the thickness of epidermis and decrease the level of ER $\beta$. The increase on the level of ER $\beta$ decrease the thickness of epidermis. It is suggested to conduct further study about the influence of OVX and physical exercise on the expression of skin steroidogenesis enzymes, skin estrogen level and IGF-1 level. The study can be conducted on older rats using much more samples. It can also use time series research, in order to examine the changes on skin structure due to longer period of physical exercise and after OVX.

\section{ACKNOWLEDGMENTS}

I express my heart-felt gratitude to $\mathrm{Mr}$ Suparno (Laboratory Assistant from Department of Physiology, Faculty of Medicine, Public Health and Nursing, Universitas Gadjahmada) and Mrs. Rumbiwati (Laboratory Assistant from Department of Parasitology, Faculty of Medicine, Pubic Health and Nursing, Universitas Gadjah Mada) who have assisted in conducting this study.

\section{REFERENCES}

1. Affinito $\mathrm{P}$, Palomba $\mathrm{S}$, Sorrentino C, Di Carlo C, Bifulco G, Arienzo $\mathrm{MP}$, et al. Effects of postmenopausal hypoestrogenism on skin collagen. Maturitas 1999; 33(3):239-47. http://dx.doi.org/10.1016/S0378-5122(99)00077-8

2. Brincat MP. Hormone replacement therapy and the skin. Maturitas 2000; 35(2):107-17.

http://dx.doi.org/10.1016/S0378-5122(00)00097-9

3. Hall G, Phillips TJ. Estrogen and skin: effects of estrogen, menopause, and hormone replacement therapy on the skin. J Am Acad Dermatol 2005; 53(4):555-68.

http://dx.doi.org/10.1016/j.jaad.2004.08.039

4. Kafantari H, Kounadi E, Fatouros M, Milonakis M, Tzaphlidou M. Structural alterations in rat skin and bone collagen fibrils induced by ovariextomy. Bone 2000; 26(4):349-53.

http://dx.doi.org/10.1016/S8756-3282(99)00279-3

5. Ozyazgan I, Liman N, Dursun N, Gunes I. The effect of ovariectomy on the mechanical properties of skin in rats. Maturitas 2002; 43(1):65-74. http://x.doi.org/10.1016/S0378-5122(02)00181-0 
6. Parchami A, Fatahian Dehkordi RA. Effect of ovariectomy and chronic sex steroid administration on rabbit skin. Global Veterinaria 2010; 4(6):610-15.

7. Hao L, Wang Y, Duan Y, Bu S. Effects of treadmill exercise training on liver fat accumulation and estrogen receptor alpha expression in intact and ovariectomized rats with or without estrogen replacement treatment. Eur J Appl Physiol 2010; 109(5):879-86. http://dx.doi.org/10.1007/s00421-010-1426-6

8. Agustiningsih D. Pengaruh olah raga teratur dan terukur terhadap kadar hormon estrogen serum wanita pasca menopause. Majalah Ilmu Faal Indonesia 2006; 51:23-34.

9. Asnawati. Ekspresi CYP19 aromatase di korteks adrenal tikus Sprague Dawley yang diovariektomi lebih tinggi akibat olah raga teratur. Tesis. Fakultas Kedokteran Universitas GadjahMada, Yogykarta 2010.

10. Bebasari E. Ekspresi CYP 19 aromatase di jaringan adipose lebih tinggi akibat olah raga teratur pada tikus Sprague Dawley yang diovariektomi. Tesis. Fakultas Kedokteran Universitas GadjahMada, Yogyakarta, 2010.

11. Rauf S. Koordinasi motorik tikus sprague dawley yang diovariektomi meningkat dengan latihan fisik teratur dan terukur kajian terhadap kadar estrogen cerebellum dan kadar reseptor estrogen- $\beta$ cerebellum. Tesis. Fakultas Kedokteran Universitas Gadjah Mada, Yogyakarta; 2012.

12. Kaidah S. Persistensi memori spasial dan kadar estrogen jaringan hippocampus tikus sprague dawley yang diovariektomi meningkat dengan latihan fisik teratur dan terukur. Tesis. Fakultas Kedokteran Universitas GadjahMada, Yogyakarta, 2012.

13. Paquette A, Wang D, Gauther MS, Prude'homme D, Jankowski M, Gudkowska J, et al. Specific adaptation of estrogen receptor $a$ and $b$ transcripts in liver and heart after endurance training in rats. Mol Cell Biochem 2007; 306(12):179-87. http://dx.doi.org/10.1007/s11010-007-9568-5

14. Sherwood L. Fisiologi manusia: dari sel kesistem. Ed. 6. Jakarta: EGC, 2007.
15. Poehlman ET, Rosen CJ, Copeland KC. The influence of endurance training on insulin-like GF-1 in older individuals. Metabolism 1994; 43(11):1401-5. http://dx.doi.org/10.1016/0026-0495(94)90035-3

16. Tavakkol A, Varani J, Elder JT, Zouboulis CC. Maintenance of human skin in organ culture: role for insulinlike GF-1 receptor and epidermal GF receptor. Arch Dermatol Res 1999; 291(12):643-51. http://dx.doi.org/10.1007/s004030050469

17. Makrantonaki E, Vogel K, Fimmel S, Oeff M, Seltmann H, Zouboulis CC. Interplay of IGF-1 and 17 $\beta$-estradiol at age-specific levels in human sebocytes and fibroblast in vitro. Exp Gerontol 2008; 43(10):939-46.

http://dx.doi.org/10.1016/j.exger.2008.07.005

18. Smith CL. Cross-talk between peptide GF and estrogen receptor signaling pathways. Biol Reprod 1998; 58(3):62732.

http://dx.doi.org/10.1095/biolreprod58.3.627

19. Haczynski J, Tarkowski R, Jarzabek $\mathrm{K}$, Slomczynska M, Wolczynski S, Magoffin DA, et al. Human cultured and skin fibroblast express estrogen receptor $\alpha$ and $\beta$. Int $\mathrm{J}$ Mol Med 2004; 10(2):149-53.

20. Gruber CJ, Tschugguel W, Shenneberger C, Huber JC. Production and actions of estrogen. N Engl J Med 2002; 346(5):340-52. htttp://dx.doi.org/10.1056/NEJMra000471

21. Lhu-The V \& Labrie F. The intracrine sex steroid biosynthesis pathways. Martiani L. editors. Neuroendocrinology: the normal neuroendocrine system, $1^{\text {st }}$ ed. Amsterdam: Elsevier; 2010. http://dx.doi.org/10.1016/s0079-6123(08)81010-2

22. Ostrowski K, Hermann C, Bangash A, Schjerling P, Nielsen JN, Pedersen BK. A trauma like elevation in plasma cytokines in human in response to treadmill running. J Physiol 1998; 513(Pt 3):889-94.

https://doi.org/10.1111/j.1469-7793.1998.889bax

23. Drenth JP, van Uum SH, van Deuren M, Presman GJ, van der ven Jongekrug J, van der Meer JW. Endurance run increases circulating IL-6 and IL-1ra but downregulates ex vivo TNF-alpha and IL-1 beta production. J Appl Physiol 
1995; 79(5):1497-503.

http://dx.doi.org/10.1152/jappl.1995.79.5.1497

24. Path G, Bornstein SR, Ehrhart-Bornstein M, Scherbaum WA. Interleukin-6 and the interleukin- 6 receptor in the human adrenal gland: expression and effects on steroidogenesis. J Clin Endocrinol Metab 1997; 82(7):2343-9.

http://dx.doi.org/10.1210/jcem.82.7.4072

25. Tracey JT. The inflammatory reflex. Nature 2002; 420:19-26. http://dx.doi.org/10.1038/nature01321

26. Rivest S. How circulating cytokines trigger the neural circuits that control the hypothalamic - pituitary - adrenal axis. Psychoneuroendocrino 2001; 26(8):761-88. http:/dx.doi.org/10.1016/S03064530(01)000646

27. Pedersen BK. Special feature for the olympics: effects of exercise on the immune system: exercise and cytokines. Immunol Cell Biol 2000; 78(5):532-5. http://x.doi.org/10.1111/j.1440-1711.2000.101-11-x

28. Gleeson M, Bishop NC, Stensel DJ, Lindley MR, Mastana SS, Nimmo MA. The anti-inflammatory effects of exercise: mechanisms and implications for the prevention and treatment of disease. Nat Rev Immunol 2011; 11(9):607-15.

http://dx.doi.org/10.1038/nri3041.

29. Ganong WF. Review of medical physiology, $22^{\text {th }}$ ed. New York: McGraw-Hill, 2005.

30. Brook CGD, Marshall NJ. Essential endocrinology. Williston: Blackwell Publishing, 2001.

31. MaiaH Jr, Casoy J, Valente J. Testosterone replacement therapy in the climacteric: benefits beyond sexuality. Gynecol Endocrinol 2009; 25(1):12-20. http://dx.doi.org/10.1080/09513590802360744.

32. Simpson ER, Rubin G, Clyne C, Robertson K, O'Donnell L, Jones M, et $a l$. The role of local estrogen biosynthesis in males and females. Trend Endocrinol Metab 2000; 11(5):184-8. https:/dx.doi.org/10.1016/S1043-2760(00)00254X

33. Stevenson S, Sharpe DT, Thornton MJ. Effect of oestrogen agonist on human dermal fibroblast in an in vitro wounding assay. Exp Dermatol 2009; 18(11):98890.

http://dx.doi.org/10.1111/j.1600-0625.2009.00864.x
34. Rittie L, Kang S, Voorhees JJ, Fisher GJ. Induction of collagen by estradiol: difference between sun-protected and photodamaged human skin in vivo. Arch Dermatol 2008; 144(9):1129-40. http://dx.doi.org/10.1001/archderm.144.9.1129

35. Ashcroft GS, Greenwell-Wild T, Horan MA, Wahl SM, Ferguson MW. Topical estrogen accelerates cutaneous wound healing in aged humans associated with an altered inflammatory response. Am J Pathol 1999; 155(4):1137-46. http:/dx.doi.org/10.1016/S0002-9440(10)65217-0

36. Lachgar $S$, Charveron $M$, Sarraute J, Mourard M, Gall Y, Bonafe JL. In vitro main pathways of steroid action in cultured hair follicle cells: vascular approach. J Investing Dermatol Symp Proc1999; 4(3):290-5.

http://dx.doi.org/10.1038/sj.jidsp.5640232

37. Fritsch M, Orfanos CE, Zouboulis CC. Sebocytes are the key regulators of androgen homeostasis in human skin. J Invest Dermatol 2001; 116(5):793-800. http://dx.doi.org/10.1046/j.0022-202x.2001.doc.x

38. Brodie A, Inkster S, Yue W. Aromatase expression in the human male. Mol Cell Endocrinol 2001; 178(1-2):23-8. http://dx.doi.org/10.1016/S0303-7207(01)00444-0

39. Gunduz F, Senturk UK, Kuru O, Aktekin B, Aktekin MR. The effect of one year's swimming exercise on oxidant stress and antioxidant capacity in aged rats. Physiol Res 2004; 53(2):171-6.

40. Hoffman-Goetz L, Pervaiz N, Guan J. Voluntary exercise training in mice increases the expression of antioxidant enzymes and decreases the expression of TNF- $\alpha$ in intestinal lymphocytes. Brain Behav Immun 2009; 23(4):498506.

http://dx.doi.org/10.1016/j.bbi.2009.01.015

41. Keylock KT, Young H. Delayed wound healing: can exercise accelerate it? Int J Exerc Sci 2010; 3(3):70-8.

42. Makrantonaki E, Vogel K, Fimmel S, Oeff M, Seltmann H, Zouboulis CC. Interplay of IGF-1 and $17 \beta$-estradiol at age-specific levels in human sebocytesand fibroblast in vitro. ExpGerontol2008; 43(10):939-46. http://dx.doi.org/10.1016/j.exger.2008.07.005

43. Fritzsche RG, Coyle EF. Cutaneous blood flow during exercise is higher 
inendurance-trained humans. J Appl Physiol 2000; 88(2):738-44. http://dx.doi.org/10.1152/jappl.2000.88.2.738

44. Iabichella ML, Melillo E, Mosti G. A review of microvascular measurements in wound healing. Int $\mathrm{J}$ Low Extrem Wounds 2006; 5(3):181-99. http://dx.doi.org/10.1177/1534734606292492

45. Gomez-Cabrera M, Domenech E, Vina $\mathrm{J}$. Moderate exercise is an antioxidant: upregulation of antioxidant genes by training. Free Radic Biol Med 2008; 44(2):126-31. hitp://dx.doi.ong/10.1016j.freeradbiomed.2007.02.001

46. Comelekoglu U, Yalin S, Balli E, Berkoz M. Ovariectomy decreases biomechanical quality of skin via oxidative stress in rat. Turk J Med Sci 2012; 42(2):201-9. http://dx.doi.org/10.3906/sag-1011-1237

47. Enoch S, Leaper DJ. Basic science of wound healing. Surgery 2007; 26(2):31-7. http://dx.doi.org/10.1016/j.mpsur.2007.11.005

48. Inoue $\mathrm{T}$, Miki $\mathrm{Y}$, Abe $\mathrm{K}$, Hatori $\mathrm{M}$, Hosaka M, Yoshiyuki K, et al. The role of estrogen-metabolizing enzymes and estrogen receptors in human epidermis. Mol Cell Endocrinol 2011; 344(1-2):3540.

http://dx.doi.org/10.1016/j.mce.2011.06.015

49. Bagamasbad $\mathrm{P} \&$ Denver RJ. Mechanisms and significance of nuclear receptor auto and cross regulation. Gen Comp Endocrinol 2011;170(1):3-17. http://dx.doi.org/10.1016/j.ygcen.2010.03.013

50. Wiik A, Hellsten Y, Berthelson P, Lundholm L, Fischer H, Jansson E. Activation of estrogen response element is mediated both via estrogen and muscle contraction in rat skeletal muscle myotubes. Am J Physiol Cell Physiol 2009; 296(1):215-20.

http://dx.doi.org/10.1152/ajpcell.00148.2008 